\title{
Torpor/hibernation cycle may enhance the risk of insecticides for bats: an in vitro study
}

\author{
Miroslava Kaňová1, Hana Band'ouchová ${ }^{1}$, Ehdaa E. E. Abdelsalam ${ }^{1}$, Petr Linhart ${ }^{1,2}$, \\ Jana Sedláčková ${ }^{1}$, Veronika Seidlová ${ }^{1}$, Jan Zukal $^{1,3}$, Jiří Pikula ${ }^{1}$ \\ ${ }^{1}$ University of Veterinary Sciences Brno, Faculty of Veterinary Hygiene and Ecology, \\ Department of Ecology and Diseases of Zoo Animals, Game, Fish and Bees, Brno, Czech Republic \\ ${ }^{2}$ University of Veterinary Sciences Brno, Faculty of Veterinary Hygiene and Ecology, \\ Department of Animal Protection and Welfare, Brno, Czech Republic \\ ${ }^{3}$ Institute of Vertebrate Biology of the Czech Academy of Sciences v.v.i., Brno, Czech Republic
}

Received October 10, 2021

Accepted November 23, 2021

\begin{abstract}
Exposure to pollutants is considered one of the potential reasons of population declines in bats. In the context of previous studies, we managed to create and keep a wide collection of cell lines from European bat species. Liver cells were chosen for testing, as they represent the preferred model for toxicological studies. Bats are protected, cell lines replacing experimental animals thus represent a unique opportunity to examine effects of pollutants which animals are exposed to in their environments. Moreover, cell incubation temperature variation may simulate physiological states of heterothermic bats. Liver cell lines were cultivated to the required cell number. Exposure to five different concentrations of permethrin (PM) and imidacloprid (IMI) were used to determine cytotoxic effects of these pesticides on Nyctalus noctula-derived liver cells cultivated at $37^{\circ} \mathrm{C}$ and $8{ }^{\circ} \mathrm{C}$ for $24 \mathrm{~h}$. An assay based on the measurement of activity of lactate dehydrogenase released from damaged cells was used for quantitating cytotoxicity. Cytotoxicity of IMI ranged from $0 \%$ to $47 \%$ and from $56 \%$ to $67 \%$ at $37^{\circ} \mathrm{C}$ and $8{ }^{\circ} \mathrm{C}$, respectively. Cytotoxicity of PM ranged from $36 \%$ to $56 \%$ and from $43 \%$ to $88 \%$ at $37{ }^{\circ} \mathrm{C}$ and $8{ }^{\circ} \mathrm{C}$, respectively. Permethrin was tested on the cells at an order of magnitude lower concentrations; even so, higher degree of cytotoxicity was recorded. Imidacloprid was more toxic to bat liver cells at a hibernation temperature than at body temperature of $37^{\circ} \mathrm{C}$.
\end{abstract}

Bats, Nyctalus noctula, hibernation, permethrin, imidacloprid, cytotoxicity

Bats represent about $20 \%$ of all mammal species and are of relevant ecological importance because of their position in the food chain, taxonomic diversity and relative longevity. They provide many essential ecosystem services like dispersal of pollen and seeds or regulation of insects (Kunz et al. 2011). On the other hand, bats are threatened by habitat disturbance and loss of roost sites, chemical and light pollution, wind turbines or diseases (Hajkova and Pikula 2007; Zukal et al. 2015; Linhart et al. 2020). Insectivorous bats occupy a relatively high trophic level which increases exposure to environmental contaminants accumulated in their diet. This leads to a higher risk of adverse effects of toxic pollutants in this group of mammals (Gaisler et al. 1998; Bartonička and Zukal 2003; Park 2015; Russo and Ancillotto 2015). Thus, exposure to pollutants, pesticides in particular, is considered one of the main reasons of declines in bat populations (Fenton 1983; Brigham 2007; Kalcounis-Rueppell et al. 2007; Bayat et al. 2014).

Neonicotinoids and pyrethroids represent two groups of commonly used pesticides. In vertebrates, neonicotinoids are presumed to have minimum toxic effects compared to organophosphate pesticides due to their selectivity for insect over vertebrate nicotinic cholinergic receptors (Tomizawa and Casida 1999). Imidacloprid (IMI) is an effective and widely used neonicotinoid pesticide (Sheets 2002). It is used for crop protection, as antiparasitic or biocide against crawling and flying insects. Popularity of IMI is due to its

Address for correspondence:

H. Band'ouchová

Department of Ecology and Diseases of Zoo Animals, Game, Fish and Bees

Faculty of Veterinary Hygiene and Ecology

University of Veterinary Sciences Brno

Palackeho tr. 1946/1, 61242 Brno, Czech Republic

Phone: +420 541562653

E-mail: bandouchovah@vfu.cz

http://actavet.vfu.cz/ 
low persistence in the soil and high efficiency at low doses (Chao and Casida 1997). It shows the fastest growing sales of any insecticide worldwide (Matsuda et al. 2001). Imidacloprid acts on nicotinic acetylcholine receptors, which function as sodium channels (Buckingham et al. 1997), where it blocks the nicotinergic neuronal pathway. This pathway is more abundant in invertebrates than in warm-blooded animals (Sheets 2002). On the other hand, IMI exposure causes neurobehavioral disorders in zebrafish (Crosby et al. 2015) with LC $_{50} 241 \mathrm{mg} / \mathrm{l}$ in Danio rerio (Tišler et al. 2009). In birds, the oral acute $\mathrm{LD}_{50}$ varies from $31 \mathrm{mg} / \mathrm{kg}$ in the Japanese quail (Coturnix japonica) to $152 \mathrm{mg} / \mathrm{kg}$ in the bobwhite quail (Colinus virginianus) (Sheets 2014). In rats and mice, the oral acute $\mathrm{LD}_{50}$ is $450 \mathrm{mg} / \mathrm{kg}$ and $150 \mathrm{mg} / \mathrm{kg}$, respectively (Tomlin 2006).

Pyrethroid insecticides are used as antiparasitics, biocides in household or pesticides in agriculture. They are highly toxic to non-target organisms such as fish and aquatic invertebrates (Clark and Matsumura 1982; Werner and Moran 2008). Permethrin (PM) as well as other pyrethroids in invertebrates interfere with the nervous system by preventing the binding of the neurotransmitter gamma amino butyric acid (GABA) at receptor sites, blocking the entry of chloride ions into the cell, causing excitement, tremors and spasms, followed by paralysis and death. Nervous impulses are disordered by prolonging activation of sodium channels, keeping them open in the neuronal membranes (repetitive effect), causing the sensorial organs and nervous terminations of the ectoparasite to react in a particularly sensitive way resulting in a state of hyperexcitation (Mencke 2006; Dong 2007). These compounds have the potential to affect bat populations by forms that are chlorinated and likely to persist in the environment. Permethrin was detected in little brown bats (Myotis lucifugus) collected in late hibernation, with concentrations ranging from 0.08 to $0.89 \mu \mathrm{g} / \mathrm{g}$ wet weight of carcass in one cave and reaching a maximum of $2.5 \mu \mathrm{g} / \mathrm{g}$ in another cave (McFarland 1998).

Bats save energy during adverse weather conditions or resource scarcity by using torpor. It is a controlled physiological state of reduced body temperature $(\mathrm{Tb})$ and metabolism (Lyman et al. 1982). The hibernation in mammals is characterized by metabolic plasticity (Nelson et al. 2008). Many organismal biochemical and physiological processes exploit low temperatures to lower reaction rates but retain the ability to resume full activity upon rewarming. However, some critical functions must continue at physiologically relevant levels during torpor and be precisely regulated even at $\mathrm{Tb}$ values near $0{ }^{\circ} \mathrm{C}$ (Carey et al. 2003). The hibernation period is composed of extended bouts of torpor lasting days to weeks that are interrupted by brief $(24 \mathrm{~h})$ periods of euthermia $\left(\mathrm{Tb} 37^{\circ} \mathrm{C}\right)$, called interbout arousals. The purpose of interbout arousals is normalization of neuronal processes, synthesis of molecules required for torpor or survival during hibernation, and general cellular maintenance (Arendt et al. 2003; Carey et al. 2003).

Immune responses during the hibernation are down-regulated (Bouma et al. 2010; Moore et al. 2013; Heger et al. 2020; Pikula et al. 2020) and activities of enzymes and functional proteins, differential regulatory controls applied to selected enzymes, mechanisms to store mRNA transcripts and to stabilize proteins, defences against ROS and muscle atrophy, and promotion of lipid catabolism are also affected by hibernation (Biggar and Storey 2009; Zeidan and Hart 2010).

Imidacloprid and PM are generally considered as low toxicity substances to warmblooded mammals, but very little is known about the impact of toxic substances on heterothermic bats during hibernation. The aim of the study was to assess the toxic effect of two commonly used insecticides: PM and IMI, on bat-derived cells in culture, because cell cultures represent a unique alternative tool for studying toxin (Kovacova et al. 2016; Abdelsalam et al. 2020; Nemcova et al. 2020) and pathogen effects (He et al. 2014; Flieger et al. 2016) in highly protected species. As the liver represents a biotransformation organ in the metabolism of xenobiotics, liver cells are the gold standard for toxicological 
testing of a wide range of chemicals (Soldatow et al. 2013). Tests were performed on liver cell lines derived from noctule bats (Nyctalus noctula) at two different temperatures of 8 and $37^{\circ} \mathrm{C}$, resembling active and non-active stages of the bat life cycle. We expected higher toxicity effects of IMI and PM on liver cell lines at a low temperature because of the reduced metabolic activity of cells. Simulating physiological states of homeiothermy and torpor, insecticidal toxicity was evaluated on the $N$. noctula liver cell line exposed for $24 \mathrm{~h}$ in culture to a scale of 5 concentrations of IMI and PM.

\section{Materials and Methods}

Liver-derived cell lines and chemicals

The primary liver cell line was obtained from Nyctalus noctula as described previously in He et al. (2014). Liver cells were cultured in DMEM medium (Merck KGaA, Darmstadt, Germany) supplemented with 10\% foetal bovine serum (Merck KGaA, Darmstadt, Germany) and 1\% penicillin/streptomycin LONZA (LONZA, Basel, Switzerland) at $37{ }^{\circ} \mathrm{C}$ in a humidified $\mathrm{CO}_{2}$ incubator of $5 \% \mathrm{CO}_{2}$. The culture medium was refreshed every 3 days and replaced with the experimental medium (DMEM medium without pyruvate (Merck KGaA, Darmstadt, Germany) with 1\% foetal bovine serum (Merck KGaA, Darmstadt, Germany) and 1\% penicillin/streptomycin LONZA (LONZA, Basel, Switzerland) for 1 day to reduce the effects of serum before treatment.

Imidacloprid $\left(\mathrm{C}_{9} \mathrm{H}_{10} \mathrm{ClN}_{5} \mathrm{O}_{2}\right)$ in PESTANAL ${ }^{\circledR}$ analytical standard (Merck KGaA, Darmstadt, Germany) was dissolved in $1 \%$ sterile ethanol (Merck KGaA, Darmstadt, Germany) and prepared in five concentrations of $0.1,1$, $10,100,1000 \mu \mathrm{g} / \mathrm{ml}$ by diluting DMEM medium without pyruvate (Merck KGaA, Darmstadt, Germany) with $1 \%$ foetal bovine serum (Merck KGaA, Darmstadt, Germany) and 1\% penicillin/streptomycin LONZA (LONZA, Basel, Switzerland). During the manipulation, IMI was protected from light. Experimental concentrations of IMI were derived from proposed toxicity reference values for bat risk assessment purposes (Mineau and Callaghan 2018).

Permethrin $\left(\mathrm{C}_{21} \mathrm{H}_{20} \mathrm{Cl}_{2} \mathrm{O}_{3}\right)$ in PESTANAL ${ }^{\circledR}$ analytical standard (Merck KGaA, Darmstadt, Germany) was dissolved in $1 \%$ ethanol (Merck KGaA, Darmstadt, Germany) and prepared in five concentrations of $0.01,0.1,1$, $10,100 \mu \mathrm{g} / \mathrm{ml}$ by diluting DMEM medium without pyruvate (Merck KGaA, Darmstadt, Germany) with $1 \%$ foetal bovine serum (Merck KGaA, Darmstadt, Germany) and 1\% penicillin/streptomycin LONZA (LONZA, Basel, Switzerland). Experimental concentrations of PM were derived from concentrations measured by McFarland in naturally exposed bats (McFarland 1998).

\section{Cytotoxicity}

Primary immortalized liver derived cells were exposed to the above-mentioned concentrations of IMI and PM. The liver cell lines were precultured to the density of $8 \times 10^{3}$ cells/well in 96 well plates, then exposed to concentrations of IMI and PM at temperatures of 8 and $37^{\circ} \mathrm{C}$ for $24 \mathrm{~h}$. The respective tests were run in septuplicates. Commercial LDH Cytotoxicity Detection kit Plus (Roche Diagnostics GmbH, Mannheim, Germany) was used for determination of cytotoxicity in line with the manufacturer's instructions. Lactate dehydrogenase (LDH) is a soluble cytosolic enzyme that is released into the culture medium following loss of cellular membrane integrity resulting from either apoptosis or necrosis. Lactate dehydrogenase activity thus can be used as an indicator of cell membrane integrity and serve as a general means to assess cell viability by measuring plasma membrane permeability. The LDH Cytotoxicity Detection kit Plus measures cell death in response to chemical compounds or environmental factors using a coupled two-step reaction. In the first step, LDH catalyses the reduction of NAD ${ }^{+}$to NADH and $\mathrm{H}^{+}$by oxidation of lactate to pyruvate. In the second step of the reaction, diaphorase uses the newly formed $\mathrm{NADH}$ and $\mathrm{H}^{+}$to catalyse the reduction of a tetrazolium salt (INT) to highly coloured formazan which absorbs strongly at 490-520 nm. Activity of LDH was determined immediately after stopping the reaction at $490 \mathrm{~nm}$ using ELx808 multi-plates reader (BioTek ${ }^{\circledR}$ Instruments, Inc. Winooski, Vermont, USA.) at laboratory temperature. Exposure was evaluated by comparison against data obtained in non-exposed controls and ethanoltreated controls for both insecticides. Measured absorbance values were then used for statistical analysis for comparison of levels of LDH in control and exposed cells. Percentage cytotoxicity (\%) was then calculated with use of average absorbance of background control, low control (spontaneous LDH release), high control (maximum LDH release) and control with $1 \%$ of ethanol as described in the manufacturer's kit instructions. Mean percentage cytotoxicity $(\%)$ for each pesticide and cultivation temperature was calculated with use of mean absorbance from all five concentrations.

\footnotetext{
Statistical analysis

Normal distribution of absorbance data (i.e., a measure of cytotoxicity through LDH activity) was tested using Kolmogorov-Smirnov and Shapiro-Wilk tests. All four datasets were normally distributed. One-way analysis of variance (ANOVA) and post hoc least significant difference (LSD) tests were used to assess the impact of different concentrations of PM and IMI on liver cells cultivated at $37^{\circ} \mathrm{C}$ and $8{ }^{\circ} \mathrm{C}$. The test for assessment of the difference between the two proportions was used for percentage cytotoxicity results analysis. All analyses were performed in Statistica for Windows ${ }^{\circledR}$ v.13.2 (StatSoft Inc., Tulsa, OK, USA). The significance level was set at $5 \%(P=0.05)$.
} 


\section{Results}

One-way ANOVA revealed highly significant differences between the absorbance measured in the IMI-exposed groups at $37^{\circ} \mathrm{C}(\mathrm{F}=4.170 ; P=0.005)$, PM-exposed groups at $8{ }^{\circ} \mathrm{C}(\mathrm{F}=4.516 ; P=0.004)$ and $\mathrm{PM}$-exposed groups at $37{ }^{\circ} \mathrm{C}(\mathrm{F}=3.820 ; P=0.007)$. There was a significant difference in IMI exposure at $8^{\circ} \mathrm{C}(\mathrm{F}=3.366 ; P=0.014)$. The post hoc test (LSD) showed significant differences between control and PM exposure groups at $37{ }^{\circ} \mathrm{C}(0.01 \mu \mathrm{g} / \mathrm{ml}, P=0.016 ; 0.1 \mu \mathrm{g} / \mathrm{ml}, P=0.042 ; 1 \mu \mathrm{g} / \mathrm{ml}, P=0.013 ; 10 \mu \mathrm{g} / \mathrm{ml}$, $P<0.001 ; 100 \mu \mathrm{g} / \mathrm{ml}, P<0.001$; Fig. 1$)$, PM exposure groups at $8{ }^{\circ} \mathrm{C}(0.01 \mu \mathrm{g} / \mathrm{ml}$, $P=0.007 ; 0.1 \mu \mathrm{g} / \mathrm{ml}, P=0.005 ; 1 \mu \mathrm{g} / \mathrm{ml}, P=0.002 ; 10 \mu \mathrm{g} / \mathrm{ml}, P<0.001 ; 100 \mu \mathrm{g} / \mathrm{ml}$, $P=0.018$; Fig. 2), in IMI exposure groups at $37^{\circ} \mathrm{C}(1 \mu \mathrm{g} / \mathrm{ml}, P=0.007 ; 100 \mu \mathrm{g} / \mathrm{ml}$, $P=0.009 ; 1000 \mu \mathrm{g} / \mathrm{ml}, P=0.004 ;$ Fig. 3$)$ and in IMI exposure groups at $8{ }^{\circ} \mathrm{C}(0.1 \mu \mathrm{g} / \mathrm{ml}$, $P=0.002 ; 1 \mu \mathrm{g} / \mathrm{ml}, P=0.009 ; 10 \mu \mathrm{g} / \mathrm{ml}, P=0.002 ; 100 \mu \mathrm{g} / \mathrm{ml}, P=0.006 ; 1000 \mu \mathrm{g} / \mathrm{ml}$, $P=0.003$; Fig. 4). There were no significant differences between controls grown in culture medium and the $1 \%$ ethanol treated cells $(P>0.05)$. While percentage cytotoxicity of IMI ranged from $1.0 \%$ to $47.9 \%$ at $37^{\circ} \mathrm{C}$ (mean percentage cytotoxicity was $29.3 \%$ ) and from $56.3 \%$ to $67.3 \%$ at $8{ }^{\circ} \mathrm{C}$ (mean percentage cytotoxicity was $62.6 \%$ ), percentage cytotoxicity of $\mathrm{PM}$ ranged from $36.3 \%$ to $56.6 \%$ at $37{ }^{\circ} \mathrm{C}$ (mean percentage cytotoxicity was $44.5 \%$ ) and from $43.9 \%$ to $88.8 \%$ at $8{ }^{\circ} \mathrm{C}$ (mean percentage cytotoxicity was $62.4 \%$ ). The test for assessment of the difference between the two proportions revealed a highly significant difference between mean percentage cytotoxicity of IMI at 8 and $37^{\circ} \mathrm{C}(P=0.007)$. The difference between mean percentage cytotoxicity of $\mathrm{PM}$ at 8 and $37^{\circ} \mathrm{C}$ was not significant $(P=0.168)$.

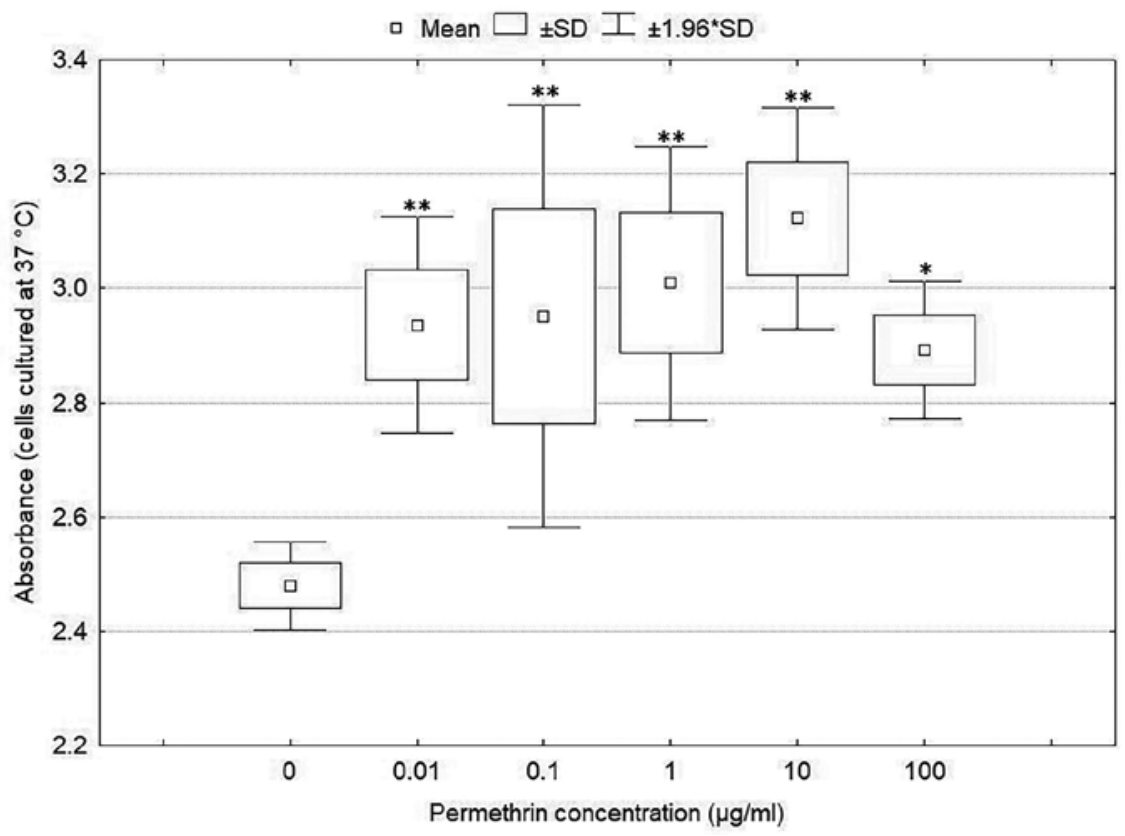

Fig. 1. Cytotoxicity of $24 \mathrm{~h}$ exposure to $\mathrm{PM}$ in bat liver cell lines at $37^{\circ} \mathrm{C}$. Lactate dehydrogenase (LDH) activity in Nyctalus noctula liver-derived cells exposed to $0.01,0.1,1,10$, and $100 \mu \mathrm{g} / \mathrm{ml} \mathrm{PM}$ for $24 \mathrm{~h}$ at $37^{\circ} \mathrm{C}\left({ }^{*}=P<0.05\right.$, $* *=P<0.01$ compared to the control cultured in medium with $1 \%$ ethanol). 


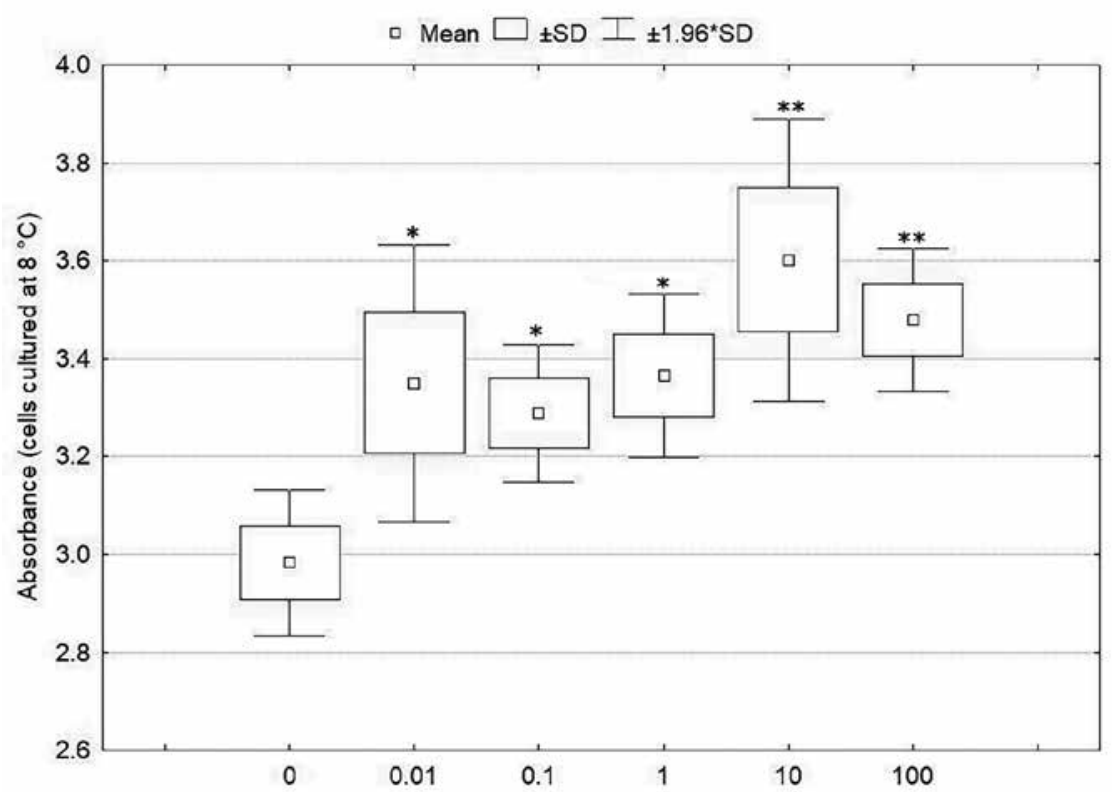

Fig. 2. Cytotoxicity of $24 \mathrm{~h}$ exposure to $\mathrm{PM}$ in bat liver cell lines at $8^{\circ} \mathrm{C}$. Lactate dehydrogenase (LDH) activity in Nyctalus noctula liver-derived cells exposed to $0.01,0.1,1,10$, and $100 \mu \mathrm{g} / \mathrm{ml} \mathrm{PM}$ for $24 \mathrm{~h}$ at $8{ }^{\circ} \mathrm{C}(*=P<0.05$, ** $=P<0.01$ compared to the control cultured in medium with $1 \%$ ethanol).

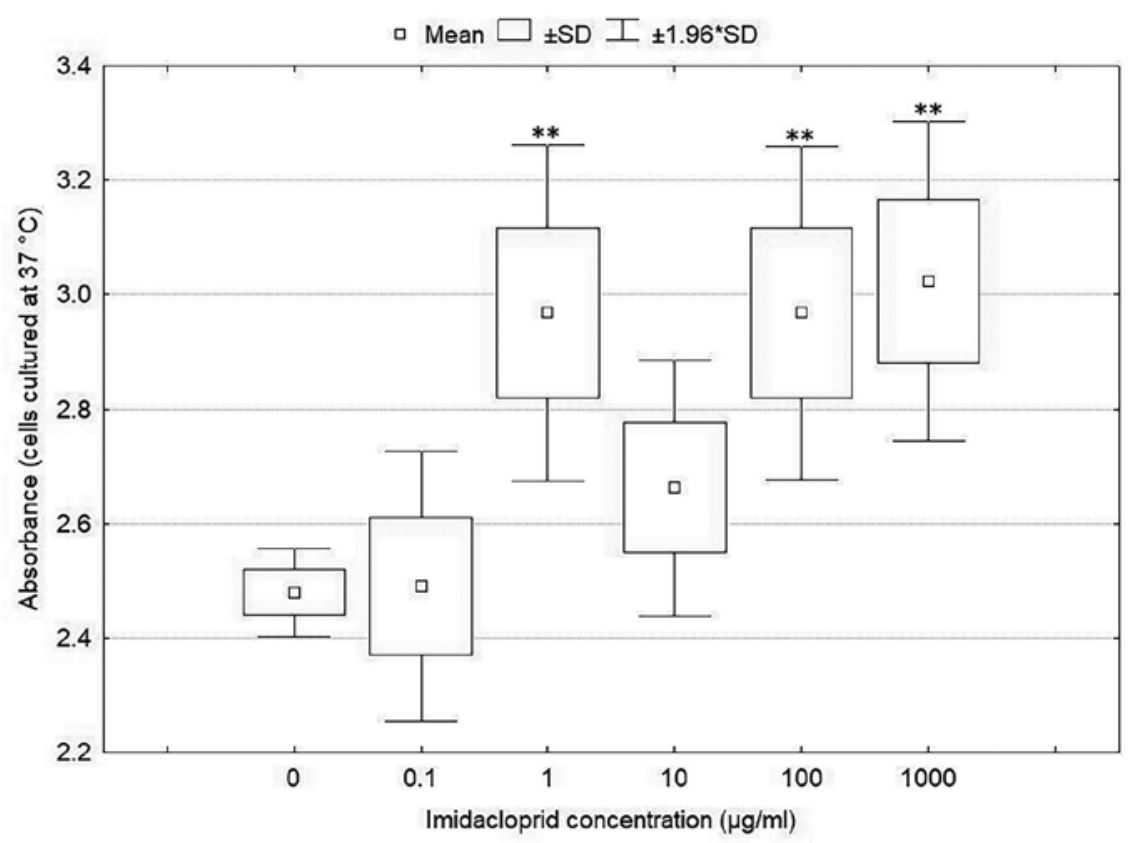

Fig. 3. Cytotoxicity of $24 \mathrm{~h}$ exposure to IMI in bat liver cell lines at $37^{\circ} \mathrm{C}$. Lactate dehydrogenase (LDH) activity in Nyctalus noctula liver-derived cells exposed to $0.1,1,10,100$ and $1000 \mu \mathrm{g} / \mathrm{ml}$ IMI for $24 \mathrm{~h}$ at $37^{\circ} \mathrm{C}(*=P<0.05$, $* *=P<0.01$ compared to the control cultured in medium with $1 \%$ ethanol). 


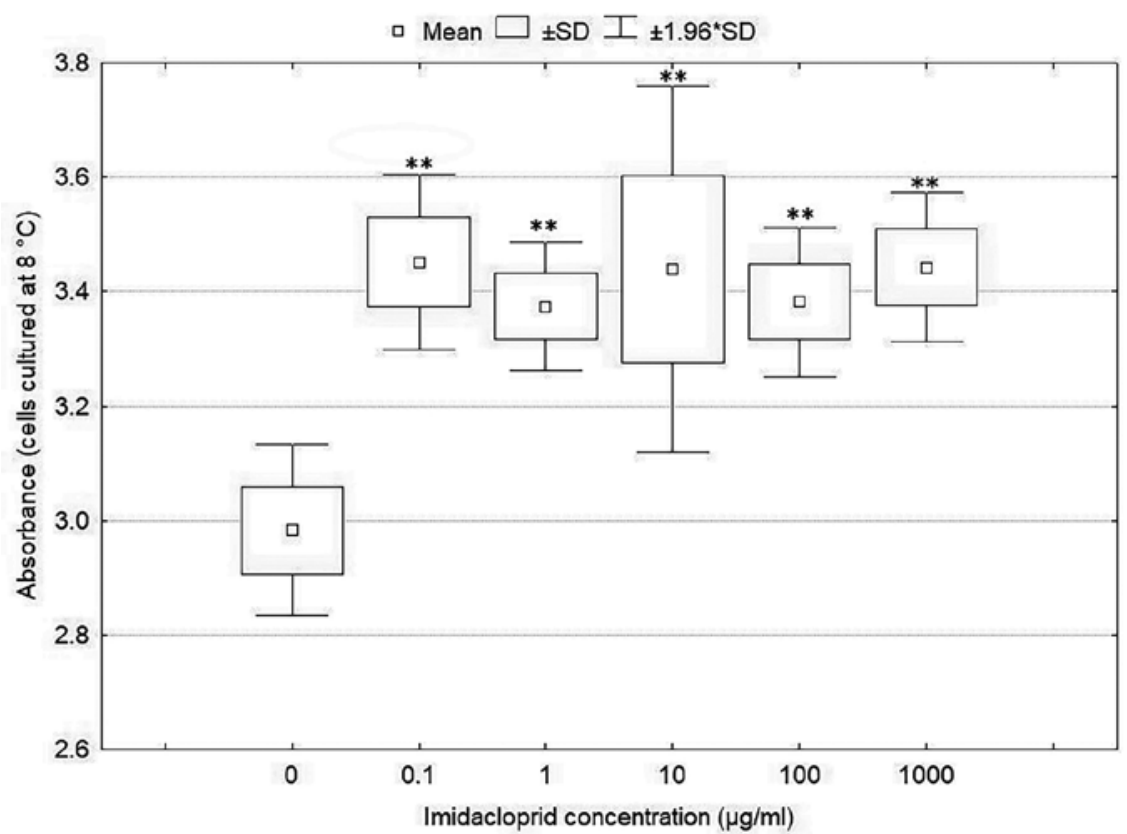

Fig. 4. Cytotoxicity of $24 \mathrm{~h}$ exposure to IMI in bat liver cell lines at $8^{\circ} \mathrm{C}$. Lactate dehydrogenase (LDH) activity in Nyctalus noctula liver-derived cells exposed to $0.1,1,10,100$ and $1000 \mu \mathrm{g} / \mathrm{ml}$ IMI for $24 \mathrm{~h}$ at $8^{\circ} \mathrm{C}\left({ }^{*}=P<0.05\right.$, ** $=P<0.01$ compared to the control cultured in medium with $1 \%$ ethanol).

\section{Discussion}

Despite the fact that pesticides are considered significant factors of bat population declines (Clark 1981; Stebbings and Griffiths 1986; Mitchell-Jones et al. 1989; Ransome 1989), only a few studies aimed at this topic (McFarland 1998; Clark and Shore 2001; $\mathrm{Wu}$ et al. 2020). Some pesticides are considered harmless to homeiothermic vertebrates and may thus be widely used as antiparasitics or crop protecting chemicals. Among these, PM and IMI are most popular in the veterinary practice as the main effective substances of tick and flea control topical preparations; they are also widely used in agriculture (Webb et al. 2003). While safe for most of the domestic mammals, pyrethroids are highly toxic to non-target organisms such as fish and aquatic invertebrates (Clark and Matsumura 1982; Werner and Moran 2008) and also for felids (Gleadhill 2004). Compared to PM, IMI shows lower toxicity in some fish species (Vignet et al. 2019), but in invertebrates its toxicity is very high.

The main route of bat exposure is probably via ingesting contaminated insects (Clark 1981). However, PM and IMI are also used for protection of wood against wood-eating insects (Berry 1977; Webb et al. 2003). Another route of bat exposure thus can be dermal absorption as a consequence to a long-term contact of juveniles and females at maternity roosts with treated wooden constructions in buildings. While both PM and IMI are not considered to have a high potential for bioaccumulation in vertebrates, some studies showed the opposite. High levels of $c i s$-permethrin were detected in rat liver after long-term low-dose per os exposure (Zamariola et al. 2017). In North America, IMI is recently used for protection of hemlock trees (Tsuga spp.) against hemlock woolly adelgid (HWA; Adelges tsugae). Bioaccumulation and toxic effects have been described in salamanders living in 
a stream near treated trees (Crayton et al. 2020) and some level of bioaccumulation of PM was described also in bats (McFarland 1998).

Our results showed a significant cytotoxic effect at $37^{\circ} \mathrm{C}$ as well as at $8{ }^{\circ} \mathrm{C}$ in liver cells exposed for $24 \mathrm{~h}$ to PM and IMI. While comparing cytotoxicity between cells cultured at $37^{\circ} \mathrm{C}$ and $8^{\circ} \mathrm{C}$, within each concentration of PM and IMI we can see the same pattern of response. The level of cytotoxicity in cells cultured at $8{ }^{\circ} \mathrm{C}$ was higher within all treatment concentrations compared to cells cultured at $37^{\circ} \mathrm{C}$. In cells exposed to $\mathrm{PM}$, the highest level of cytotoxicity was $56.6 \%$ and $88.9 \%$ at $37^{\circ} \mathrm{C}$ and $8{ }^{\circ} \mathrm{C}$, respectively, while in IMI it was $47.9 \%$ and $67.3 \%$ at $37^{\circ} \mathrm{C}$ and $8{ }^{\circ} \mathrm{C}$, respectively. Although PM was tested on the cells at an order of magnitude lower concentrations, the same degree of cytotoxicity was achieved at $8^{\circ} \mathrm{C}$ (mean percentage cytotoxicity in PM and IMI was $62.4 \%$ and $62.6 \%$, respectively) and higher percentage cytotoxicity was found at $37{ }^{\circ} \mathrm{C}$ (mean percentage cytotoxicity in PM and IMI was $44.5 \%$ and $29.3 \%$, respectively). Based on the significant difference between mean percentage cytotoxicity, it can be stated that IMI is more toxic to bat liver cells at a temperature of $8{ }^{\circ} \mathrm{C}$ (simulating hibernation temperature) than at $37^{\circ} \mathrm{C}$ (representing active body temperature). In PM, the difference between mean percentage cytotoxicity at $8{ }^{\circ} \mathrm{C}$ and $37^{\circ} \mathrm{C}$ was not significant. This can be due to potentially higher toxicity of PM to bat liver cells, thus exposure to lower concentrations would be more appropriate for further studies.

Since bats hibernate over the unfavourable period with a lack of food in the temperate zone, with their hibernation temperature ranging between 0 and $12^{\circ} \mathrm{C}$ (Webb et al. 1996), the presence of PM and IMI in their environment and bioaccumulation in their adipose tissue may pose a serious risk. Both substances are lipophilic, so they can be expected to accumulate in adipose tissues, which is essentially the only source of energy for bats during hibernation. While during the autumn there is an intensive storage of fat reserves in the form of brown and yellow adipose tissue, during hibernation, fat reserves are mobilized during arousal bouts (Kunz et al. 1998) and thus lipophilic toxins can be released and act on the animal's organs. In addition, during hibernation, there is a significant reduction not only in metabolic processes in the animal, but also a significant reduction in detoxification mechanisms. In Rhinolophus ferrumequinum, activity of cytochrome P450, family 1, subfamily A, polypeptide 2 (CYP1A2) gene was significantly down-regulated during the torpid state (Xiao et al. 2015) and the same pattern is present also in other hibernators (Williams et al. 2005). As cytochrome P450 enzymes represent an important part of pathway for detoxification of both PM and IMI, this can also contribute to a more severe impact of these insecticides on cells cultured at low temperatures.

However, it should be noted that this study represents a model of short-term exposure. In the case of long-term exposure, other mechanisms that are not activated within the short-term exposure may be involved. On the one hand, the organism may adapt to longacting toxic substances in the sense of increasing the detoxification capacity (Klement et al. 2020). On the other hand, in case of absence of adaptation mechanisms, even lower concentrations may represent a risk (Williams et al. 2005; Xiao et al. 2015).

Last but not least, it should be considered that when testing toxic substances in cell culture, we lack other interactions, pathways, and bonds that exist in the whole organism and may be involved in modifying the response to a particular toxic substance (LeCluyse et al. 2012). This can significantly affect the outcome of such exposure, as mechanisms that are bound to organs or cell types in the body other than those found in the cell line used are also involved in the process of restoring homeostasis following exposure to adverse substances (Astashkina et al. 2012).

To conclude, our study revealed significant cytotoxic effects of both tested substances, with more pronounced effects in cells cultured at a low temperature. Permethrin and IMI may thus represent a serious potential threat for hibernating bats, as detoxification mechanisms 
used by hepatocytes are down-regulated during hibernation. The bioaccumulation potential of these insecticides has long been overlooked, but especially in the case of insectivorous hibernators this issue needs to be addressed. More complex transcriptome focused studies will be necessary to identify specific mechanisms behind the cytotoxic effects of PM and IMI in bat liver cells.

\section{Acknowledgments}

We are grateful to Dr. Kevin Roche for correction and improvement of the English text. This study was supported through Grant No. 235/2015/FVHE of the Internal Grant Agency of the University of Veterinary Sciences Brno.

\section{References}

Abdelsalam EEE, Bandouchova H, Heger T, Kanova M, Kobelkova K, Nemcova M, Piacek V, Sedlackova J, Seidlova V, Vitula F, Pikula J 2020: Polychlorinated biphenyl toxicity in the thyroid gland of wild ungulates: an in vitro model. Acta Vet Brno 89: 151-162

Arendt T, Stieler J, Strijkstra AM, Hut RA, Rüdiger J, Van der Zee EA, Harkany T, Holzer M, Härtig W 2003: Reversible paired helical filament like phosphorylation of tau is an adaptive process associated with neuronal plasticity in hibernating animals. J Neurosci 23: 6972-6981

Astashkina A, Mann B, Grainger DW 2012: A critical evaluation of in vitro cell culture models for high-throughput drug screening and toxicity. Pharmacol Ther 134: 82-106

Bartonicka T, Zukal J 2003: Flight activity and habitat use of four bat species in a small town revealed by bat detectors. Folia Zool 52: 155-166

Bayat S, Geiser F, Kristiansen P, Wilson SC 2014: Organic contaminants in bats: Trends and new issues. Environ Int 63: 40-52

Berry RW 1977: The evaluation of permethrin for wood preservation. Pestic Sci 8: 284-290

Biggar KK, Storey KB 2009: Perspectives in cell cycle regulation: lessons from an anoxic vertebrate. Curr Genomics 10: $573-584$

Bouma HR, Carey HV, Kroese FGM 2010: Hibernation: the immune system at rest? J Leukoc Biol 88: 619-624

Brigham RM 2007: Bats in forests: conservation and management. In: Lacki ML, Hayes JP, Kurta A (Eds): What we know and what we need to learn. Johns Hopkins University Press, MD, Baltimore, pp. 1-15

Buckingham SD, Lapied B, Le Corronc H, Grolleau F, Sattelle DB 1997: Imidacloprid actions on insect neuronal acetylcholine receptors. J Exp Biol 200: 2685-2692

Carey HV, Andrews MT, Martin SL 2003: Mammalian hibernation: cellular and molecular responses to depressed metabolism and low temperature. Physiol Rev 83: 1153-1181

Chao LS, Casida JE 1997: Interaction of imidacloprid metabolites and analogs with the nicotinic acetylcholine receptor of mouse brain in relation to toxicity. Pestic Biochem Physiol 58: 77-88

Clark DR, Shore RF 2001: Chiroptera. In: Shore RF, Battner BA (Eds): Ecotoxicology of wild mammals. John Wiley \& Sons, Ltd., London, pp. 108-114

Clark DR 1981: Special Scientific Report Wildlife. Bats and Environmental Contaminants: A Review. US Department of the Interior, Fish and Wildlife Service, Washington DC, $235 \mathrm{p}$.

Clark JM, Matsumura F 1982: Two different types of inhibitory effects of pyrethroids on nerve $\mathrm{Ca}^{-}$and $\mathrm{Ca}+\mathrm{Mg}$-atpase activity in the squid, Loligo pealei. Pestic Biochem Physiol 18:180-190

Crayton SM, Wood PB, Brown DJ, Millikin AR, McManus TJ, Simpson TJ, Kang-Mo Ku Yong-Lak Park 2020: Bioaccumulation of the pesticide imidacloprid in stream organisms and sublethal effects on salamanders. GECCO 24: e01292

Crosby EB, Bailey JM, Oliveri AN, Levinb ED 2015: Neurobehavioral impairments caused by developmental imidacloprid exposure in zebrafish. Neurotoxicol Teratol 49: 81-90

Dong K 2007: Insect sodium channels and insecticide resistance. Invert Neurosci 7: 17-30

Fenton MB 1983: Just Bats. Toronto Buffalo, University of Toronto, London, 165 p.

Flieger M, Bandouchova H, Cerny J, Chudíčková M, Kolarik M, Kovacova V, Martínková N, Novák P, Šebesta O, Stodůlková E, Pikula J 2016: Vitamin B2 as a virulence factor in Pseudogymnoascus destructans skin infection. Sci Rep 6: 33200

Gaisler J, Zukal J, Rehák Z, Homolka M 1998: Habitat preference and flight activity of bats in a city. J Zool 244: $439-445$

Gleadhill A 2004: Permethrin toxicity in cats. Vet Rec 155: 648

Hajkova P, Pikula J 2007: Veterinary treatment of evening bats (Vespertilionidae) in the Czech Republic. Vet Rec 161: $139-140$

He X, Korytar T, Zhu Y, Pikula J, Bandouchova H, Zukal J, Köllner B 2014: Establishment of Myotis myotis cell lines - model for investigation of host-pathogen interaction in a natural host for emerging viruses. Plos One 9: e109795

Heger T, Zukal J, Seidlova V, Nemcova M, Necas D, Papezikova I, Piacek V, Zajickova R, Bandouchova H, Pikula J 2020: Measurement of phagocyte activity in heterotherms. Acta Vet Brno 89: 79-87 
Kalcounis-Rueppell MC, Payne VH, Huff SR, Boyko AL 2007: Effects of wastewater treatment plant effluent on bat foraging activity in an urban stream system. Biol Conserv 134: 120-130

Klement W, Oliviero F, Gangarossa G, Zub E, De Bock F, Forner-Piquer I, Blaquiere M, Lasserre F, Pascussi J-M, Maurice T, Audinat E, Ellero-Simatos S, Gamet-Payrastre L, Mselli-Lakhal L, Marchi N 2020: Lifelong Dietary Pesticide Cocktail Induces Astrogliosis Along with Behavioral Adaptations and Activates p450 Metabolic Pathways. J Neurosci 446: 225-237

Kovacova V, Abdelsalam EEE, Bandouchova H, Brichta J, Havelkova B, Piacek V, Vitula F, Pikula J 2016: Cytotoxicity of ketamine, xylazine and Hellabrunn mixture in liver-, heart- and kidney-derived cells from fallow deer. Neuroendocrinol Lett 37: 78-83

Kunz TH, Braun de Torrez E, Bauer D, Lobova T, Fleming T 2011: Ecosystem services provided by bats. Ann. N.Y. Acad Sci 1223: 1-38

Kunz TH, Wrazen JA, Burnett CD 1998: Changes in body mass and fat reserves in prehibernating little brown bats (Myotis lucifugus). Écoscience 5: 8-17

LeCluyse EL, Witek RP, Andersen ME, Powers MJ 2012: Organotypic liver culture models: Meeting current challenges in toxicity testing. Crit Rev Toxicol 42: 501-548

Linhart P, Bandouchova H, Zukal J, Votýpka J, Kokurewicz T, Dundarova H, Apoznański G, Heger T, Kubickova A, Nemcova M, Piacek V, Sedlackova J, Seidlova V, Berkova H, Hanzal V, Pikula J 2020: Trypanosomes in Eastern and Central European bats. Acta Vet Brno 89: 69-78

Lyman CP, Willis JS, Malan A, Wang LCH 1982: Hibernation in mammals and birds. Academic Press, New York, $320 \mathrm{p}$.

Matsuda K, Buckingham SD, Kleier D, Rauh JJ, Grauso M, Sattelle DB 2001: Neonicotinoids: insecticides acting on insect nicotinicacetylcholine receptors. Trends Pharmacol Sci 22: 573-580

McFarland CA 1998: Potential agricultural insecticide exposure of Indiana bats (Myotis sodalis) in Missouri. University of Missouri, Missouri, Colombia, $256 \mathrm{p}$.

Mencke N 2006: Acaricidal and repellent properties of permethrin, its role in reducing transmission of vectorborne pathogens. Parassitologia 48: 139-140

Mineau P, Callaghan C 2018: Neonicotinoid insecticides and bats: an assessment of the direct and indirect risks. Canadian Wildlife Federation, 87 p.

Mitchell-Jones AJ, Cooke AS, Boyd I.L, Stebbings RE 1989: Bats and remedial timber treatment chemicals a review. Mamm Rev 19: 93-110

Moore MS, Reichard JD, Murtha TD, Nabhan ML, Pian RE, Ferreira JS, Kunz TH 2013: Hibernating little brown myotis (Myotis lucifugus) show variable immunological responses to white-nose syndrome. PLoS ONE 8: 58976

Nelson CJ, Otis JP, Martin SL, Carey HV 2008: Analysis of the hibernation cycle using LC-MS-based metabolomics in ground squirrel liver. Physiol Genomics 37: 43-51

Nemcova M, Pikula J, Zukal J, Seidlova V 2020: Diclofenac-induced cytotoxicity in cultured carp leukocytes. Physiol Res 69: 607-618

Park K 2015: Mitigating the impacts of agriculture on biodiversity: bats and theirpotential role as bioindicators. Mamm Biol 80: 191-204

Pikula J, Heger T, Bandouchova H, Kovacova V, Nemcova M, Papezikova I, Piacek V, Zajíčková R, Zukal J 2020 : Phagocyte activity reflects mammalian homeo- and hetero-thermic physiological states. BMC Vet Res 16: 232

Ransome RD 1989: Population changes of greater horseshoe bats studied near Bristol over the past twenty-six years. Biol J Linn Soc 38: 71-82

Russo D, Ancillotto L 2015: Sensitivity of bats to urbanization: a review. Mamm Biol 80: 205-212

Sheets LP 2002: The Neonicotinoid Insecticides. In: Massaro EJ (Ed.): Handbook of Neurotoxicology Vol. 1. Chapter 6, NJ: Humana Press, Totowa, pp. 79-87

Sheets LP 2014: Imidacloprid. In: Anderson B, de Peyster A, Shayne CG, Hakkinen PJ, Kamrin M, Locey B, Mehendale HM, Pope C, Shugart L (Eds): Encyclopedia of Toxicology, pp. 1000-1003

Soldatow VY, Lecluyse EL, Griffith LG, Rusyn I 2013: In vitro models for liver toxicity testing. Tox Res 2: 23-39

Stebbings RE, Griffiths F 1986: Distribution and status of bats in Europe. Institute of Terrestrial Ecology, Huntingdon, $142 \mathrm{p}$.

Tišler T, Jemec A, Mozetic B, Trebše P 2009: Hazard identification of imidacloprid to aquatic environment. Chemosphere 76: $907-914$

Tomizawa M, Casida JE 1999: Minor structural changes in nicotinic insecticides confer differential subtype selectivity for mammalian nicotinic acetylcholine receptors. Br J Pharmacol 127: 115-122

Tomlin CDS 2006: The Pesticide Manual, a World Compendium. 14 ${ }^{\text {th }}$ edn; British Crop Protection Council, Surry, England, pp. 598-599

Vignet C, Cappello T, Fu Q, Lajoie K, De Marco G, Clérandeau C, Mottaz H, Maisano M, Hollender J, Schirmer $\mathrm{K}$, Cachot J 2019: Imidacloprid induces adverse effects on fish early life stages that are more severe in Japanese medaka (Oryzias latipes) than in zebrafish (Danio rerio). Chemosphere 225: 470-478

Webb PI, Speakman JR, Racey PA 1996: How hot is a hibernaculum? A review of the temperatures at which bats hibernate. Can J Zool 74: 761-765

Webb RE, Frank JR, Raupp MJ 2003: Eastern hemlock recovery from hemlock woolly adelgid damage following imidacloprid therapy. J Arboric 29: 298-302 
Werner I, Moran K 2008: Effects of pyrethroid insecticides on aquatic organisms. ACS Symp Ser 991: 310-334

Williams DR, Epperson LE, Li W, Hughes MA, Taylor R, Rogers J, Martin SL, Cossins AR, Gracey AY 2005: Seasonally hibernating phenotype assessed through transcript screening Physiol Genomics 24: 13-22

Wu CH, Lin CL, Wang SE, Lu CW 2020: Effects of imidacloprid, a neonicotinoid insecticide, on the echolocation system of insectivorous bats. Pestic Biochem Physiol 163: 94-101

Xiao Y, Wu Y, Sun K, Wang H, Zhang B, Song S et al. 2015: Differential Expression of Hepatic Genes of the Greater Horseshoe Bat (Rhinolophus ferrumequinum) between the Summer Active and Winter Torpid States. PLoS ONE 10: 0145702

Zamariola N, Toledo Netto P, da Silva Franchi CA, de Camargo JLV, de Marchi MRR 2017: QuEChERS-Based Method for Pesticides Analysis in Adipose Tissue Associated with Rat Ovaries. J Anal Toxicol 41: 399-406

Zeidan Q, Hart GW 2010: The intersections between O-GlcNAcylation and phosphorylation: implications for multiple signaling pathways. J Cell Sci 23: 13-22

Zukal J, Pikula J, Bandouchova H 2015: Bats as bioindicators of heavy metal pollution: history and prospect. Mamm Biol 80: 220-227 